\title{
FROM QUEEN'S COLLEGE TO RUTGERS COLLEGE
}

\author{
BY THOMAS J. FRUSCIANO \\ fruscian@rulmail.rutgers.edu
}

Why is Rutgers University named for a wealthy bachelor who resided in New York City? What was his involvement with the institution of higher learning we now call Rutgers, The State University of New Jersey? Those familiar with the university's past know that Colonel Henry Rutgers provided much needed financial assistance at a time when the institution was just getting back on its feet; they may also be aware that the bell hanging in the cupola of Old Queens was a gift from him. But to understand why this lifelong New Yorker supported a small denominational college in New Brunswick, we must examine what took place following the American Revolution and during the early years of the 19th century.

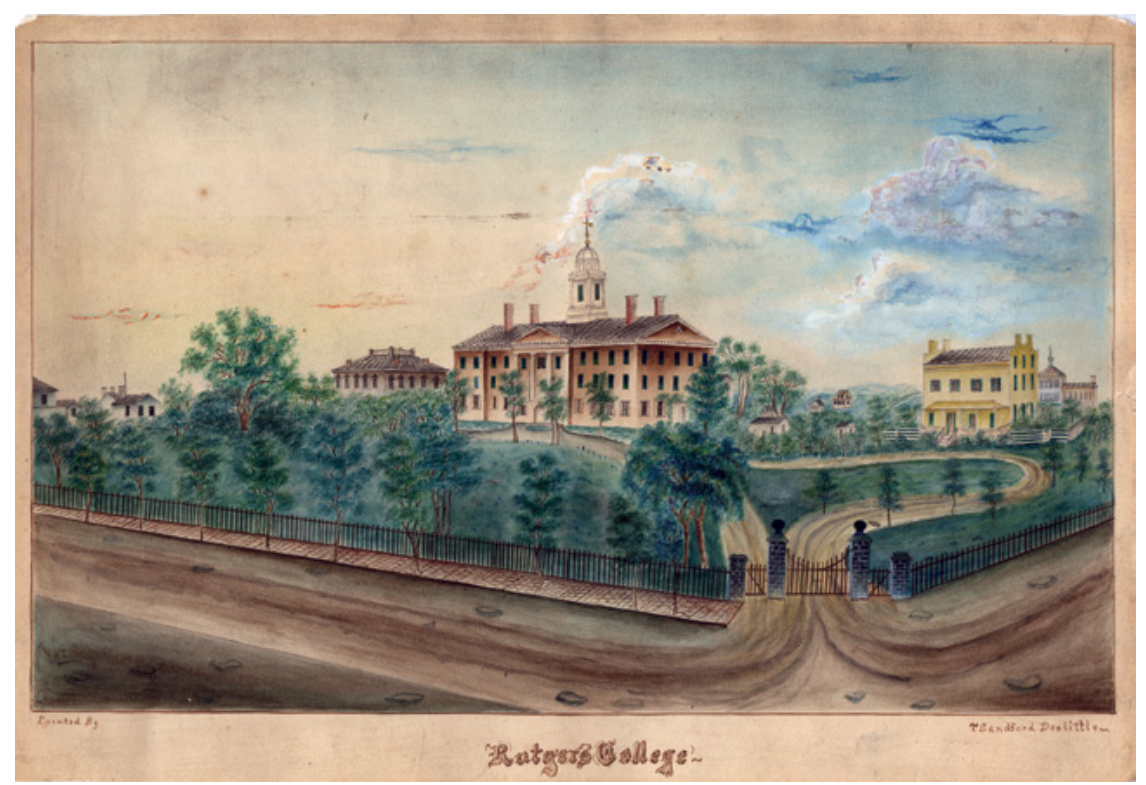

Watercolor painting of Rutgers College, late 1850s, by Theodore Doolittle, Class of 1859

http://dx.doi.org/10.14713/irul.v68i1.1952

The Journal of the Rutgers University Libraries, Volume 68, pp. 19-28.

JRUL is licensed under a Creative Commons Attribution-NoncommercialNoDerivs 4.0 United States License. 
Queen's College was founded in 1766 by a faction of the Reformed Dutch Church to provide collegiate instruction for those aspiring to the ministry as well as for those who were to enter the learned professions of law, medicine, and education. And much of the college's early history is tied directly to its relationship with the church and its principal governing body-the General Synod. The college-with few students and limited finances-struggled throughout the post-Revolutionary era, existing much of that time without a president. By 1795, following failed merger negotiations with the College of New Jersey at Princeton and rejecting a proposal from the Synod to move the college closer to the Dutch populations in Northern New Jersey, New York City, and the Hudson River Valley, the college trustees voted to suspend undergraduate instruction, maintaining operation of its Grammar School, which was established in New Brunswick in $1768 .^{1}$

The college remained closed for 12 years. In 1807, Andrew Kirkpatrick, Chief Justice of New Jersey, urged his fellow trustees to begin raising funds for a new building and commence collegiate instruction once again. The plan was to send agents throughout New York and New Jersey to solicit funds for the college, particularly targeting members of the Reformed Church. As a courtesy and as a prudent measure, the trustees informed the General Synod and various church officials in New York City and Albany of their intentions. A straightforward plan to raise money suddenly became a complicated affair, with dire consequences for Queen's College.

By 1806 the General Synod had begun to raise funds in support of its theological professor, Rev. John Henry Livingston, who had been providing instruction in New York City since 1784 . With that goal in mind, church authorities in New York responded to the Queen's College appeal by offering their assistance and proposing that support solicited by the college in New York be directed into a fund for "the education of young men for the ministry and the establishment of a Theological School."2 The Queen's trustees agreed to the proposal and entered into a covenant with the church-the Covenant of 1807. Its essential features specified that all funds raised in New York were to constitute a fund to support a theological professorship in the college (the Professoral Fund), and when adequate funds were secured the college would fill the professorship with the candidate nominated by the Synod. On their part, the Synod agreed to contribute a proportional 
share of the costs for building "Old Queens." Furthermore, governance of what would become the "Theological Institution of Queen's College" would be under the direction of a "Board of Superintendents," accountable to the Synod and not the trustees. ${ }^{3}$

With an agreement reached, students appeared at the George Street home of Queen's College for undergraduate instruction in September 1807. Soon the trustees accepted a gift of land from the heirs of Perth Amboy resident James Parker that constitutes the present site of the Queen's campus, where the architectural plans of John McComb were soon to be realized. On April 27, 1809 the cornerstone of Old Queens was laid, with appropriate ceremonies.

Although classes were underway and the new building well advanced, there was still no president of Queen's College. The trustees extended the offer to Rev. John Henry Livingston, the Synod's professor of theology and patriarch of the Reformed Church. Following an exchange of correspondence on terms and condition of his service, Livingston initially declined the offer. The trustees responded by assuring him that his responsibilities were to be minimal-preside over commencement, authenticate documents, and take general superintendence of the institution as far as his time and health would permit. With the primary emphasis of his duties on theological instruction, the 64 year-old Livingston accepted the presidency of Queen's College and assumed office in September 1810.

While the theological instruction prospered under Livingston, the college soon faced new financial difficulties. The costs of construction for Old Queens had exceeded the amount of money raised and the trustees' attempt to conduct a lottery fell far short of the expected $\$ 20,000 .{ }^{4}$ Money promised for the Professoral Fund was not forthcoming and obligations for Livingston's salary and house rent were not met. And to make matters worse, local banks were now demanding payment on the college's accumulating debt. Despite a valiant effort on the part of the trustees, it became obvious by 1814 that they had failed in their mission to stabilize the institution.

When the Synod learned about the college's troubles, they responded with a plan to transform Queen's College into a theological seminary, which would also provide instruction in classical subjects. They proposed that three professors of theology be appointed by the Synod and a professor of mathematics and natural philosophy be appointed by the trustees. The trustees would 
pay the full salary of their professor and half the salary of Synod's professors. In addition to theological instruction, the Synod's professors would also devote a portion of their time teaching undergraduates. ${ }^{5}$

While the trustees accepted much of the plan, problems arose over details and no agreement was reached. Operating at a loss of nearly $\$ 4,000$ over the preceding three years, and incurring additional debt, primarily from building Old Queens that totaled $\$ 7,000$, the trustees confronted an inescapable and unfortunate decision. In April 1816, they debated a plan that called for suspending undergraduate instruction and turning the building over to the Reformed Dutch Church for use as a theological school. Final action on the proposal was deferred for a month. On May 29, 1816, the trustees of Queen's College voted eleven to four in favor of closing the college. Among those voting in favor of closing the college was Henry Rutgers. ${ }^{6}$

Colonel Rutgers was elected as a member of the Board of Trustees of Queen's College on September 25, 1815, during the same meeting in which the Rev. Philip Milledoler was also elected as a trustee. The two men had formed a close relationship in New York City, though they were 30 years apart in age. ${ }^{7}$

In 1793 Milledoler graduated from Columbia College. Later that year he joined New York City's Nassau Street German Reformed Church, studied under its pastor, John Gros, and earned his license to preach. Upon his mentor's death in 1795, Milledoler took over the church and served for the next five years. In 1800 he moved to Philadelphia's Pine Street Presbyterian Church but returned to New York three years later and became pastor of the Rutgers Street Presbyterian Church, one of several churches built on land donated by Colonel Rutgers. Milledoler held various offices under the General Assembly of the Presbyterian Church, serving as moderator of the Assembly in 1808 and providing theological instruction until the founding of the Princeton Theological Seminary in 1812. In 1813 he accepted a call from the Reformed Dutch Church and soon became pastor of the Market Street Dutch Reformed Church at its founding in 1817, serving with distinction until he was called to New Brunswick in 1825 to become president of Queen's College. ${ }^{8}$

In 1798 Henry Rutgers became an elder, a member of the Session, and a trustee of the Rutgers Street Presbyterian Church. It was here where he forged his close relationship with Milledoler. In 1819, when the Market Street Dutch Reformed Church was 
completed on land that he donated, Henry Rutgers joined his friend Milledoler and served faithfully as an elder until his death in 1830. It was during these years when Rutgers also served as president of the Board of Corporation of the Reformed Dutch Church, a position that placed him in an interesting position when discussions turned to the General Synod's relationship with the trustees of Queen's College.

Rutgers' attendance at meetings in New Brunswick was infrequent. Besides the crucial meeting of 1816 when Queen's College was closed, Rutgers' only other appearance was at a two-day meeting of the trustees in September 1817. By 1821 his inability to attend meetings "by a variety of circumstances and because of Rheumatic affection" forced him to resign his position on the board. But his position and leadership in the General Synod certainly kept him directly involved with the college. ${ }^{9}$

While Queen's College languished, the seminary had gained new strength. In 1814 Rev. Elias Van Bunschooten donated \$17,000 for aiding students preparing for the ministry, and the following year Ms. Rebecca Knox of Philadelphia provided a \$2,000 gift for the same purpose. The trustees were the custodians of both funds because the General Synod of the Dutch Reformed Church at the time was not an incorporated body and doubt existed as to its ability to hold and expend funds. In 1817, the Synod proposed that the Seminary should be moved to New York City, where several wealthy churches pledged $\$ 6,000$ annually to support such an institution. But the trustees countered by stressing the advantage of New Brunswick as a location remote from the evil influences of the city. They also asserted that such a move was an infringement of the 1807 agreement between the Synod and the college trustees. Most importantly, the trustees could not apply the funds under their control to the support of a theological school "except in connection with Queen's College."10

The Synod struck back with a series of efforts to secure the funds away from the trustees' control and by 1820 the trustees finally agreed to relinquish control of the Professoral Fund, but only if the seminary stayed in New Brunswick. The two parties remained deadlocked on the issue.

By 1823 Queen's College was in severe financial trouble and trustees felt obliged to sell its building to the Synod in order to eliminate its debts. The time was right for the Synod to press its advantage, which would have certainly resulted in the complete 


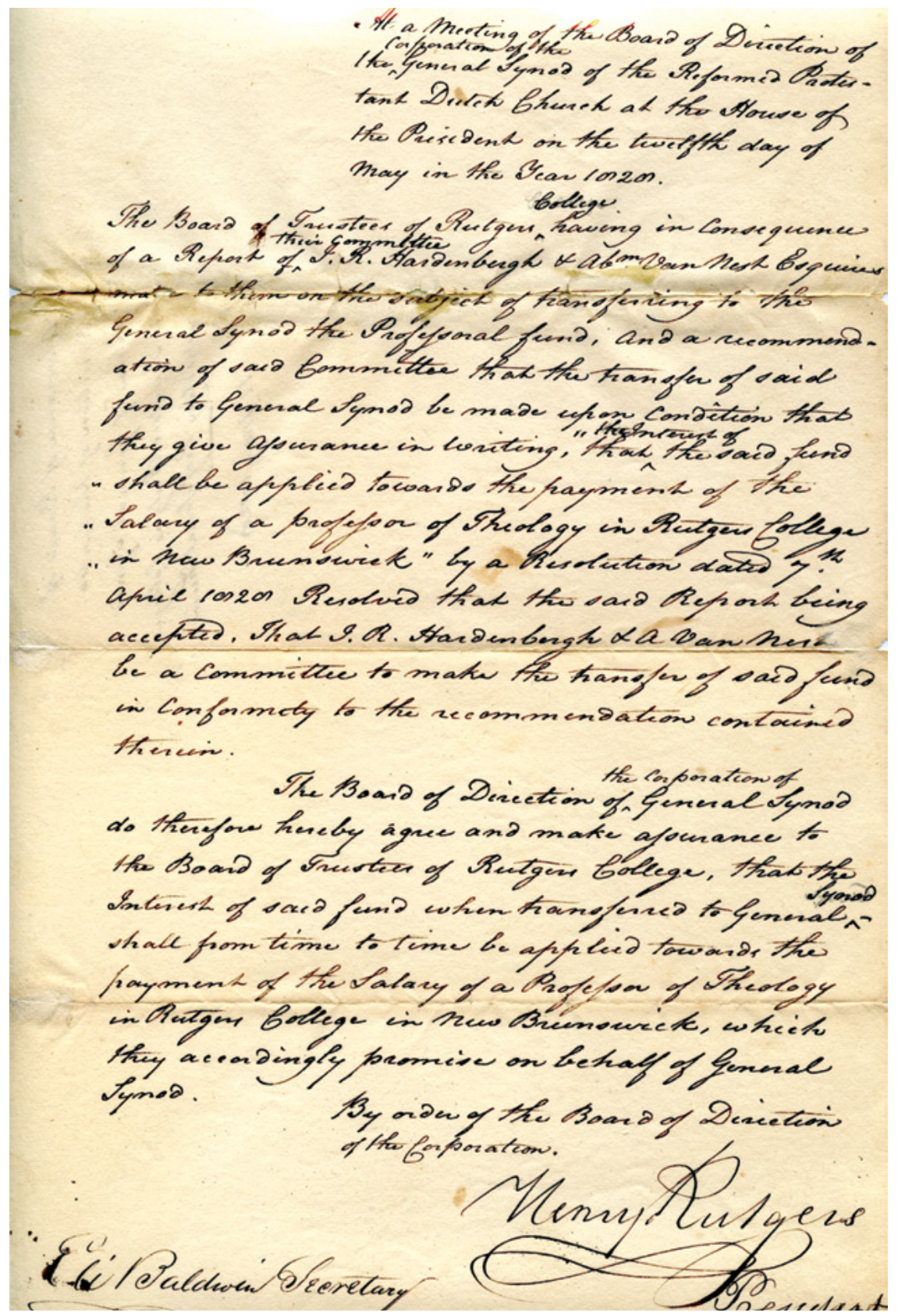

An order to transfer the Professoral fund to the General Synod under condition that interest of the fund shall be applied toward the salary for a professor of theology to Rutgers College. Signed by Henry Rutgers as President of the Board of Corporation of the Reformed Dutch Church, May 12, 1828. 
extinction of Queen's College. But by this time sentiment had changed within the church hierarchy, and its members now sought a congenial and mutually beneficial solution to the problem. A new round of negotiations began that would ultimately lead to the revival of the college on a permanent basis-not as "Queen's College" but as "Rutgers College."

In 1822 the Synod had appointed a committee to raise $\$ 25,000$ to support a second theological professorship. By this time the Synod was recognized as a corporate body in the State of New York and would be in command of its own funds. Jacob R. Hardenbergh, son of the first president of Queen's College and a member of its Board of Trustees, was the most active member of the Synod's fundraising committee and he successfully raised more than the intended amount. At the same time, the college trustees sprang back into action with the prospects of raising funds through another college lottery. This time it would be managed by the New York firm of McIntyre and Yates, specialists in the management of lotteries, who guaranteed a return of $\$ 20,000$ to the College. The idea was approved by the New Jersey legislature, with the stipulation that the money obtained would be invested as an endowment for a professorship of mathematics. The lottery was conducted throughout 1824 , only to be stopped when the State of New Jersey intervened. But McIntyre and Yates honored its commitment to Queen's College. ${ }^{11}$

With the addition of a newly-endowed professorship, and with its debts cleared by the sale of Old Queen's to the Synod, the trustees began to formulate plans to revive the college. At the same time the Synod appointed a committee to develop a plan in consultation with the trustees. By September 1825, in a special meeting in New Brunswick, the Synod announced the success of a subscription for a third professorship and placed on the table a plan to resurrect Queen's College, to become known as the Covenant of 1825.

The Covenant, essentially a revision of the agreement reached in 1807, made possible the resumption of undergraduate education but control in the affairs of the institution shifted to the Synod. The Synod agreed to allow the trustees use of space in Old Queen's and to assign the theological professors with teaching duties in the undergraduate department. The trustees, in turn, were to appoint one of the theological professors as president of the college and they were required to name the professor of mathematics 
and the professor of languages and pay their salaries. No other professors were to be appointed without consent of the Synod. If the college was no longer able to support these professorships, the Synod might be called upon for assistance, but the Synod also reserved the right to dissolve its connection with the college if such assistance would deplete the funds dedicated to the Theological Seminary. Both the Synod and the Queen's trustees approved the new arrangements and the opening of the college took place on November 14, 1825, with 30 students in attendance. ${ }^{12}$

With the resumption of undergraduate instruction, Queen's College acquired a new name. Reverend Philip Milledoler-who was named professor of didactic theology in May 1825 in addition to his position on the Board of Trustees-held discussions with Jacob Hardenbergh on changing the name of Queen's College, suggesting that the institution be named in honor of Colonel Henry Rutgers. At a meeting of the trustees in September 1825, where discussions centered on the plans to revive the college, Milledoler was elected as president of Queen's College. And the trustees gave their unanimous approval to his suggestion to change the name from Queen's to Rutgers College. At the same time the Synod also gave its approval to the name change. A petition was submitted to the New Jersey Legislature, which was approved on December 5, 1825. As a devoted member of the Reformed Dutch Church, Henry Rutgers epitomized those Christian qualities held in high esteem by the Synod and the college trustees. While changing the name of the college in honor of Henry Rutgers, the Synod and the trustees were also signaling a break from an uneven past and the start of a new and promising era. ${ }^{13}$ 
In March 1826, at a meeting of the Board of Corporation of the Reformed Dutch Church held at the Rutgers mansion, a resolution was read and adopted that its president, Colonel Henry Rutgers, had generously determined to bestow an annual donation to Rutgers College in perpetuity. The gift was the interest on a $\$ 5,000$ bond that he presented to the General Synod of the Reformed Dutch Church, to be paid semi-annually to the college trustees. If the college ceased to exist, the money would be directed to the Synod in support of a theological professorship. Another donation to the college was also presented by Colonel Rutgers- $\$ 200$ for the purchase of a bell to be hung in the cupola erected on Old Queen's through the generosity of Stephen Van Rensselaer. ${ }^{14}$

While his contributions to the college in New Brunswick ended in 1826, Henry Rutgers' position as president of the Board of Corporation of the Dutch Reformed Church required his attention on matters relating to the church's relationship with the Rutgers College trustees. As for Milledoler, his presidency initiated a period of prosperity for Rutgers College. But by the early 1830 s the tranquil relationship between the Synod and the college soon deteriorated and Milledoler found himself at the center of controversy. He resigned the presidency in 1839 but stayed on an additional year until a successor could be named. But it was Rev. Philip Milledoler and the Reformed Dutch Church who brought the college's attention to Henry Rutgers. Many, including student Jacob Van Arsdale from the Class of 1830, expected further gifts from Henry Rutgers, particularly upon his death in $1830 .{ }^{15}$ None were forthcoming. But we do have the bell and the name "Rutgers," a name that has endured for nearly two centuries!

\section{NOTES}

1. For a detailed account of the early years of Queen's College, see Richard P. McCormick, Rutgers: A Bicentennial History (New Brunswick, NJ: Rutgers University Press, 1966) and William H. S. Demarest, A History of Rutgers College (New Brunswick, NJ: Rutgers College, 1924). On the attempted merger with The College of New Jersey (Princeton), see Thomas J. Frusciano, "To Cultivate Piety, Learning, and Liberty: The College of New Jersey and Queen's College, 1746-1794," Journal of the Rutgers University Libraries, Vol. LV, No. 2 (December 1993), 1-29. http://dx.doi.org/10.14713/irul. v55i2.1726. 
2. Acts and Proceedings of the General Synod of the Reformed Protestant Dutch Church in North America, (New York, 1859). Vol 1., p. 363.

3. A recent discussion of the Covenant of 1807 as well as the Reformed Church's efforts to establish a theological professorship is contained in John W. Coakley, New Brunswick Theological Seminary: An Illustrated History (Grand Rapids, MI: William B. Eerdmans Publishing Company, 2014), 1-26.

4. On the Queen's College Literature Lottery, see Philip G. Nordell, "The Rutgers Lotteries," Journal of the Rutgers University Library XVI, no. 1 (December 1952), 1-12.

5. "Plan for a Theological College" in Queen's College, Rutgers College and Rutgers University Board of Trustees: Manuscript Minutes, Enclosures, and Subject Files, 1778-1956 (RG 03/A0/02), Box 1, Folder 16. (Hereafter cited as BOT Minutes and Enclosures).

6. Queen's College Board of Trustees Minutes, May 29, 1816 (RG 03/ $\mathrm{A} 0 / 01)$.

7. Queen's College Board of Trustees Minutes, September 25, 1815.

8. A biographical essay on Milledoler is contained in Thomas J. Frusciano, "Leadership on the Banks: Rutgers' Presidents, 17661991," Journal of the Rutgers University Libraries LIII, no. 1 (June 1991), 11-12.

9. Queen's College Board of Trustees Minutes, 1817; Henry Rutgers to William Deare, May 28, 1822 in BOT Minutes and Enclosures, Box 2, Folder 2.

10. McCormick, Rutgers, A Bicentennial History, 33-34; Demarest, A History of Rutgers College, 246-248; 256.

11. Nordell, "The Rutgers Lotteries," 7-11.

12. BOT Minutes and Enclosures, Box 2, Folder 5.

13. Documents relating to the change in name from Queen's to Rutgers College are found in the BOT Minutes and Enclosures, Box 2, Folder 3.

14. Minutes of the Board of Corporation of the Reformed Dutch Church, March 31, 1826, contained in the BOT Minutes and Enclosures, Box 2, Folder 5.

15. Jacob Van Arsdale to Isaac Van Arsdale, March 15, 1830 in Jacob R. Van Arsdale Letters, 1827-1835 (R-MC 027), Box 3, Folder 9. 